thermodynamics of the reversible cell. The two following chapters deal with gaseous reactions and with the thermodynamies of dilute solutions. The concluding chapter on the entropy constant and the Nernst theorem contains a few hints of quantum mechanical concepts.

The book is inexpensive and will form a useful addition to the shelves of the student of physics or physical chemistry.

A. F.

\section{Properties of Matter}

By D. N. Shorthose. Revised edition. Pp. viii +168 . (London: William Heinemann, Ltd., 1937.) $4 s$.

$\mathrm{T}$ HE author intends this book for higher school certificate and scholarship examinations. In the section on dynamics the general relations of mass and motion are assumed, as the book begins with a chapter on circular motion, followed by one on simple harmonic motion. It is doubtful whether the use of initials in place of the names of quantities is really an advantage. A few are, of course, well recognized, such as E.M.F. and H.P., but the use of M.I., P.E. and K.E. is questionable.

The chapter on gravitation follows the usual lines, but the fact that the attraction of a uniform sphere is the same as that of an equal mass at the centre is assumed. The chapter on surface tension is par. ticularly good. Then follow friction and elasticity, omitting beams.

In the second edition a chapter on viscosity has been added for the sake of completeness. Throughout the book are numerous worked examples, and at the end of each chapter is a set of examples which the student will find extremely useful.

\section{Travel}

Stepping Stones from Alaska to Asia

By Isobel Wylie Hutchison. Pp. $\mathrm{x}+246+20$ plates. (London, Glasgow and Bombay : Blackie and Son, Ltd., 1937.) 12s. 6d. net.

7 HIS makes no pretensions at being a scientific compilation; it is merely "a little record of a happy summer". Nevertheless, it will delight the scientific worker with a taste for semi-adventurous travel not only because of its breezy narrative and vivid descriptions of new and noteworthy features offered by a little-known part of the world, but also because of the highly commendable (and unfortunately quite unusual) care with which the author has followed the dictates of specialists who have worked in the region concerned. This region is, primarily, the Alaskan-Aleutian Chain, which extends in graceful curve but treacherous seas nearly 2,000 miles westwards from north-west America towards Asia. Such notes as we are given on its flora and ethnology are right up to date, the theorizing being correspondingly restrained, with the result that we are presented with a record which will be of definite value to all who are interested in the life and surface features of the North Pacific.

The few small blemishes are in most cases un- warranted generalizations concerning other parts of the globe. Thus some places spoken of as being in northern Greenland are in reality far south on that great 'continent', even if their district is known to the inhabitants as "North Greenland", while the reviewer has seen Greenland (and also Baffin) Eskimo devour ravens with marvellous dispatch, and has even joined in the feast with no ill-effect or hint at a 'taboo'; he has also found Spiranthes Romanzoffiana growing wild in many places much nearer to the British Museum than Alaska or even Hudson Bay !

The author is an energetic Scottish woman, apparently of middle-age-an ardent and experienced, if technically untrained, botanical collector-with grit and perseverance as outstanding attributes. Now here lies a poignant indication; she has recently visited several of the least accessible regions in the world alone and without 'expedition press' or acclamation as a 'heroic explorer', which suggests once more that the epoch of such things and people is drawing to its natural close, and that its place is being taken by one of serious scientific investigation and honest travel.

N. P.

The Black Musketeers:

the Work and Adventures of a Scientist on a South Sea Island at War and at Peace. By A. J. Marshall. Pp. xiii $+329+35$ plates. (London : William Heinemann, Ltd., 1937.) 15s. net.

$\mathrm{M}^{\mathrm{s}}$ R. MARSHALL'S "Black Musketeers" are the Melanesian inhabitants of Espiritu Santo, the most northerly island of the New Hebrides group. The name by which he calls them is not so fanciful as it may seem. Their characteristic weapon, once the bow, is now the old Snider musket, a relic of the mid-nineteenth century.

Mr. Marshall, a young Australian, who had already won his spurs as an explorer and ornithologist on his own continent, joined Mr. Tom Harrisson, a member of the Oxford University Exploration Club's expedition to the New Hebrides. $\mathrm{He}$ was left behind by the expedition for a further year's observational work on the causes of a breeding season in animals and plants. The subjects of the investigation were birds, bats and lizards, of which specimens were collected for dissection at stated periods throughout the year. Meteorological observations were made and recorded daily. The routine work was certainly strenuous; but nevertheless the two colleagues had ample opportunity, as is shown in "Savage Civilisation", the book by Mr. Harrisson covering the same period, to make friendly and in some instances intimate contacts with the natives. Their most exciting adventure here recorded was an inter-village war, in which they barely escaped being involved; while a hurricane provided its share of thrills by partially wrecking their camp. Mr. Marshall is no less strong than Mr. Harrisson in his condemnation of the English. French condominium ; but the work of the mission. aries, however much it may have been misdirected in the past, is now accorded its meed of praise. 